CLINICAL STUDY

\title{
Obestatin/ghrelin cells in normal mucosa and endocrine tumours of the stomach
}

\author{
Apostolos V Tsolakis ${ }^{1}$, Lars Grimelius ${ }^{3}$, Mats Stridsberg ${ }^{2}$, Sture E Falkmer ${ }^{4,5}$, Helge L Waldum ${ }^{6}$, Jan Saras ${ }^{1}$ \\ and Eva T Janson ${ }^{1}$ \\ ${ }^{1}$ Section of Endocrine Oncology, Department of Medical Sciences, Departments of ${ }^{2}$ Clinical Chemistry and ${ }^{3}$ Genetics and Pathology, University Hospital, \\ 75185 Uppsala, Sweden, ${ }^{4}$ Department of Pathology, the St Olav University Hospital, Trondheim 7006, Norway, ${ }^{5}$ Department of Clinical Pathology and \\ Cytology, the Ryhov County Hospital, Jönköping 551 85, Sweden and ${ }^{6}$ Department of Gastroenterology, the St Olav University Hospital, \\ Trondheim 7006, Norway
}

(Correspondence should be addressed to A V Tsolakis; Email: apostolos.tsolakis@medsci.uu.se)

\begin{abstract}
Objective: Obestatin and ghrelin are derived from the same gene and co-expressed in the same endocrine cells. Vesicular monoamine transporter-2 (VMAT-2), a marker for enterochromaffin-like (ECL) cells, is considered to be expressed in ghrelin cells. The aim was to establish if the two peptides and the transporter are co-expressed, both in normal gastric mucosa and in gastric endocrine tumours. Design: An immunohistochemical study was performed on gastric biopsy material and on surgical specimens from 63 patients with gastric endocrine tumours and from individuals with normal gastric mucosa. Cells displaying obestatin immunoreactivity were examined regarding co-localization with ghrelin and VMAT-2. Both single- and double-immunostaining techniques were applied. Obestatin concentration in blood was measured in a subgroup of these patients. The results were correlated to various clinico-pathological parameters.

Results: In the normal mucosa, obestatin/ghrelin-immunoreactive cells rarely co-expressed VMAT-2. In most tumour tissue specimens, only a fraction of neoplastic cells displayed immunoreactivity to obestatin, and these cells always co-expressed ghrelin. Neoplastic obestatin-/ghrelin-IR cells invariably expressed VMAT-2, except for two ghrelinomas. The obestatin concentrations in blood were consistently low and did not correlate to clinico-pathological data.

Conclusions: Obestatin and ghrelin immunoreactivity always occurred in the same endocrine cells in the gastric mucosa but these cells only occasionally co-expressed VMAT-2, opposite to the findings in tumours. These results indicate that endocrine cells expressing obestatin and ghrelin mainly differ from VMAT-2 expressing cells (ECL-cells) and can develop into pure ghrelinomas. Plasma concentrations of obestatin did not correlate to cellular expression.
\end{abstract}

European Journal of Endocrinology $160941-949$

\section{Introduction}

Obestatin is a 23 amino-acid peptide that derives from the processing of preproghrelin (1). It is believed to be produced mainly in the gastric mucosa, but its receptor is still a matter of some controversy (1-4). In rodents, there are indications that obestatin is involved in the faculty of memory, has anxiolytic effects and inhibits thirst $(5,6)$. In man, it has been suggested that obestatin may have an effect in longterm bodyweight regulation and that the preprandial ghrelin to obestatin ratio may play a role in the pathophysiology of obesity $(7,8)$. The hormone ghrelin is involved in the regulation of bodyweight by stimulating appetite and it is the endogenous ligand of $\mathrm{GH}$ secretagogue receptor subtype $1 \mathrm{a}(9,10)$. It has been shown that ghrelin stimulates gastrointestinal motility in humans $(11,12)$. The stimulatory effects of ghrelin on gastric motility may be mediated by vagal nerve or directly by ghrelin receptors in the stomach (11). Furthermore, administration of ghrelin accelerates gastric emptying and improves meal-related symptoms in patients with gastroparesis $(13,14)$. In man, the ghrelin-immunoreactive ( $-I R)$ cells occur mainly in the fundus-corpus mucosa of the stomach and co-express obestatin $(15,16)$. It has been reported that ghrelin cells in gastric mucosa express the vesicular monoamine transporter-2 (VMAT-2), which is an immunohistochemical (IHC) marker for the enterochromaffin-like cells (ECL-cells) of the oxyntic mucosa and, consequently, also for ECL-cell carcinoids (ECL-CCs) (17-19).

Numerous ghrelin-IR cells appear in most gastric endocrine tumours, and in cells in areas of endocrine cell hyperplasia in mucosa (20-23). Two malignant endocrine tumours with hyperghrelinaemia have been 
described, one originating from pancreas and one from gastric mucosa $(24,25)$. Recent studies have also indicated that ghrelin-IR cells present in gastric ECL-CCs and in foci of the adjacent mucosa with concomitant ghrelin cell hyperplasia, are not related to concentrations of circulating ghrelin (23).

The aims of the present study were i) to characterize normal gastric mucosa, foci of endocrine cell hyperplasia, and different gastric endocrine tumours, with respect to the occurrence of obestatin-IR cells and their relation to ghrelin and VMAT-2 expression, and ii) to measure plasma concentrations of obestatin and correlate these findings to clinico-pathological parameters.

\section{Materials and methods}

\section{Patients and tumours}

Biopsy and/or gastric resection specimens from 63 patients with primary gastric endocrine tumour, and metastases from 21 of these cases, were collected from the Laboratories of Pathology at the University Hospital in Uppsala, Sweden and St Olav's University Hospital in Trondheim, Norway. Non-tumorous oxyntic mucosa surrounding the tumours was also included with a view to examine the possible existence of foci of endocrine cell hyperplasia. Most of these tumours had been included in an earlier study (23). The tumours were classified as type I $(n=37)$, type II $(n=3)$, type III $(n=9)$ ECL-CCs, non-ECL-CC $(n=1)$, ghrelinomas $(n=2)$ and poorly differentiated endocrine carcinomas (PDECs; $n=11$ ) from which four were of small cell and seven of large cell type (26). The primary diagnosis in the 21 cases of metastases included in this study was: type I $(n=3)$, type II $(n=1)$, type III $(n=6)$, ECL-CCs, ghrelinomas $(n=2)$ and PDECs $(n=9)$. One of the patients with type III ECL-CCs suffered from atypical carcinoid syndrome. Furthermore, the tumours were also classified according to the recently presented staging system based on TNM classification (see Tables 1 and 3) (27).

\section{Control tissues}

Control tissue biopsies were from fundus, corpus and antrum mucosa of 14 adults. Six specimens were from patients operated for gastric adenocarcinoma, eight from biopsies obtained on gastroscopy. All the control tissues examined originated from macro- and microscopically normal gastric mucosa. The surgical specimens were located at least $3 \mathrm{~cm}$ from the neoplasm. The patients who underwent gastroscopy suffered from epigastralgia. In the tissue samples obtained from the gastric endocrine tumours, peritumorous mucosa was also used as an internal control.

Table 1 Summary of clinical and tumour characteristics.

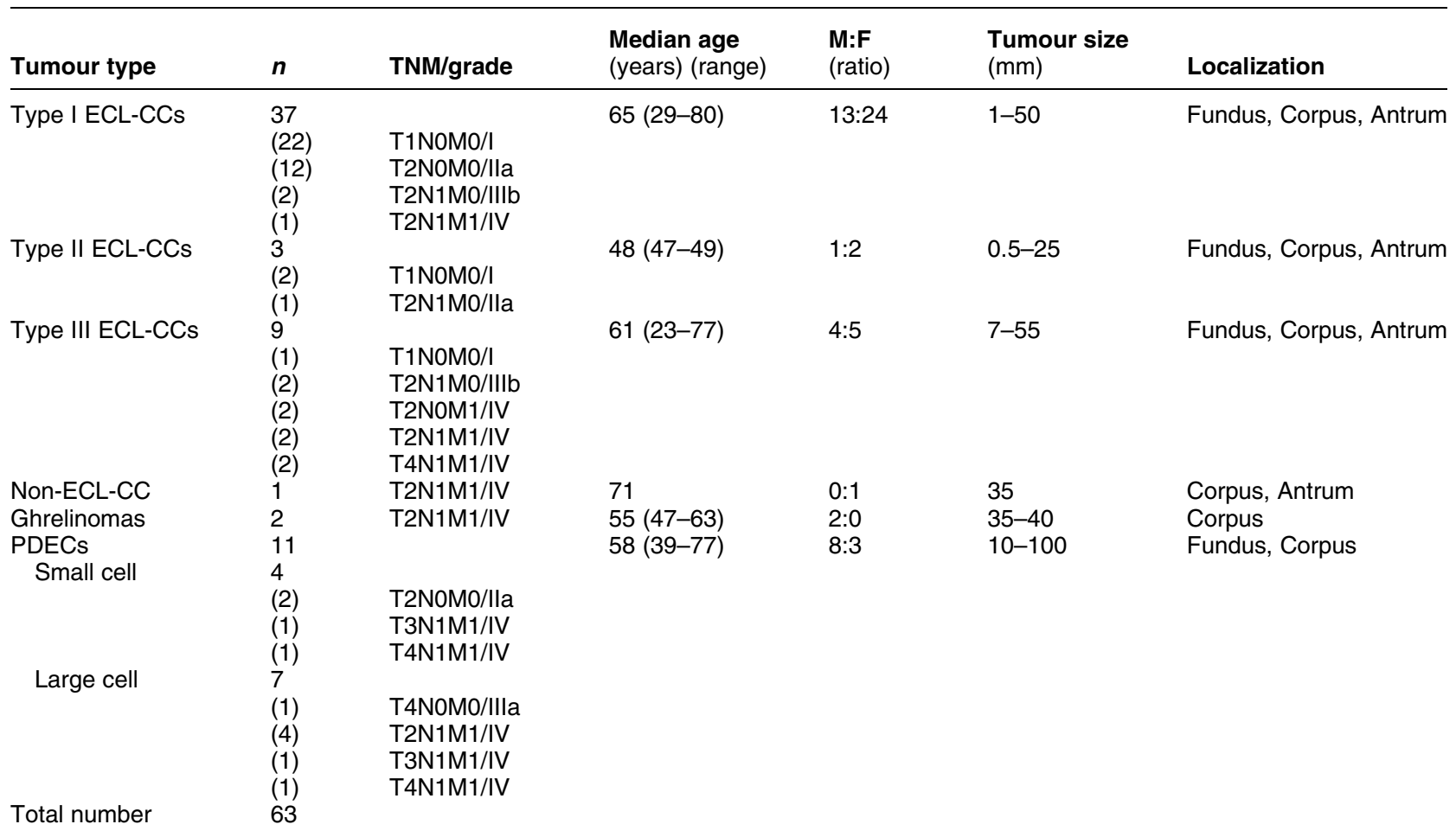

M, male; F, female; TNM/grade according to Rindi et al. (27); ECL-CCs, enterochromaffin-like cell carcinoids; PDECs, poorly differentiated endocrine carcinomas. 


\section{Development of obestatin antibodies}

A 23 amino acid peptide, identical with human obestatin with an additional amino-terminal cysteine residue, was synthesized. The peptide was coupled via the cysteine residue to maleimide-activated keyhole limpet hemocyanin. Free peptide was removed by dialysis. A rabbit was immunized with the peptidecarrier complex using a standard immunization procedure. The antibody raised against obestatin peptide was used both for RIA and for IHC investigation. The specificity of the antibody has been proven previously by western blot (16).

\section{Routine staining and IHC}

All the tissue samples were fixed in 10\% buffered neutral formalin and routinely processed to paraffin wax. Consecutive sections, $\sim 4 \mathrm{~mm}$ thick, were attached to positively charged glass slides (SuperfrostPlus; Menzel Gläser, Braunschweig, Germany). The sections were routinely stained with haematoxylin-eosin. For the IHC classification of the tumours, the sections were immunostained with general and specific neuroendocrine markers using a polymer detection system (DakoCytomation (Glostrup, Denmark), EnVision+ system-HRP, K4010 for primary rabbit antibodies and K4006 for primary mouse antibodies), except for the immunostaining of the goat VMAT-2 antibody where the avidin biotin complex technique (Vectastain ABC PK-6100 (Vector Laboratories, Burlingame, CA, USA)) was used with a biotinylated horse anti-goat secondary antibody (BA-9500, Vector Laboratories, 1:100). Diaminobenzidine was the final chromogen. The primary antibodies used are summarized in Table 2. Before immunostaining, the sections were microwave treated for $2 \times 5 \mathrm{~min}$ at $750 \mathrm{~W}$; using Tris buffer saline, $\mathrm{pH} 8.0$, as retrieval solution.

\section{Double immunofluorescence}

Co-localization studies were performed using immunofluorescence technique with the primary antibodies presented in Table 2.
For double immunofluorescence staining, the sections were microwave treated for $2 \times 5 \mathrm{~min}$ at $750 \mathrm{~W}$ in Tris buffer saline, $\mathrm{pH} 8.0$; and then incubated overnight with a cocktail of two primary antibodies at $4{ }^{\circ} \mathrm{C}$. Before application of the antibody cocktail, the sections were incubated with a mixture of non-immune sera from the animal species producing the secondary antibodies, diluted 1:10. The secondary antibodies used were: tetramethyl rhodamine isothiocyanate (TRITC)-conjugated donkey anti-chicken (703-025-155, Jackson Immuno Research Laboratories (PA, USA) 1:100); FITC-conjugated donkey anti-chicken (703-095-155, Jackson Labs, 1:100); swine anti-rabbit FITC-conjugated (F 0205, DakoCytomation, 1:100); goat anti-rabbit (TRITC) conjugated antibody (111-075-003, Jackson Labs, 1:100) and biotinylated horse anti-goat (BA-9500, Vector Laboratories, 1:100). As fluorochrome, for the biotinylated secondary antibody, streptavidin-Texas Red (SA-5006, Vector Laboratories) was used. TRITC and Texas Red chromogens give rise to red fluorescence and FITC to green. Incubation time of the secondary antisera was $30 \mathrm{~min}$ at room temperature. To minimize unspecific staining and ensure species specificity, the secondary antibody in question was preincubated overnight at $4{ }^{\circ} \mathrm{C}$ with $10 \mu \mathrm{l} / \mathrm{ml}$ normal serum both from the animal species recognized by the other secondary antibody and from the species producing the other secondary antibody. The sections were examined in a Zeiss Axioplan2 fluorescence microscope and photographed with an AxioCam HRm camera employing Axiovision imaging software and a $63 \mathrm{X}$ plan-apochromat objective. The co-localization studies were based on sections from normal fundus $(n=3)$, corpus $(n=3)$ and antrum $(n=3)$; and from type I $(n=5)$, type II $(n=1)$, type III ECL-CCs $(n=2)$, ghrelinoma $(n=1)$ and PDECs $(n=2)$.

\section{Antibody specificity tests}

Specificity tests were performed for the ghrelin, obestatin and the two different VMAT-2 antibodies, in conventional IHC analyses and in double immunofluorescence staining. Control immuno-staining included omission of the primary antisera, and

Table 2 List of antibodies used in immunohistochemistry.

\begin{tabular}{|c|c|c|c|c|}
\hline Antibody raised to & Code & Source/reference & Dilution & Species \\
\hline Chromogranin A & LK2H10 & Boehringer, Mannheim, Germany & $1: 24000$ & Mouse \\
\hline Ghrelin & $\mathrm{H}-031-30$ & Phoenix Pharmaceuticals, Belmont, CA, USA & $1: 7200$ & Rabbit \\
\hline Ghrelin & Y-031-44 & Phoenix Pharmaceuticals & $1: 800(\mathrm{IF})$ & Chicken \\
\hline Obestatin & - & Gronberg et al. (16) & $1: 8000 / 1: 800$ (IF) & Rabbit \\
\hline Serotonin & M0758 & DakoCytomation, Denmark & $1: 200$ & Mouse \\
\hline Somatostatin & A0566 & DakoCytomation & $1: 6000$ & Rabbit \\
\hline Synaptophysin & A0010 & DakoCytomation & $1: 800$ & Rabbit \\
\hline VMAT-2 & AB1767 & Chemicon International, Temecula, CA, USA & $1: 800 / 1: 50$ (IF) & Rabbit \\
\hline VMAT-2 & C-20, sc-7721 & Santa Cruz Biotechnology ${ }^{\circledR}$, Santa Cruz, CA, USA & 1:2400/1:200 (IF) & Goat \\
\hline
\end{tabular}

IF, immunofluorescence. 
replacement of the primary antibody by non-immune serum at the same dilution as the primary antibody in question and in the same diluent. A neutralization test was conducted by a 24-h incubation of primary antiserum with the relevant antigen $(10 \mathrm{nmol}$ antigen per ml diluted antibody solution) before application to the sections. Furthermore, the ghrelin and obestatin primary antibodies were also used in crossneutralization tests.

Obestatin, ghrelin or VMAT-2 antiserum preabsorbed with the respective peptide did not give rise to immunostaining. The same finding was seen after the omission of the primary antiserum in question or its replacement by non-immune serum. When the ghrelin and obestatin antibodies were incubated with the antigen used to raise the other antibody, the immunoreactivity remained unchanged. In double immunostaining, the omission of one of the primary antibodies or its replacement by non-immune serum gave an immunostaining pattern corresponding to that obtained with the remaining primary antibody. After the neutralization test or the omission of both antisera, the controls were non-IR.

\section{Plasma samples}

Blood samples from 31 patients included in the histopathological part of the study, were collected after an overnight fast and before initiation of treatment. Of these patients, 15 had type I, two type II and eight type III ECL-CCs. A patient with a malignant ghrelinoma was also included, as well as five patients with PDECs, two of small-cell type and three of large cell type.

Blood samples were also collected from 67 healthy individuals (28 men and 39 women, age range 18-67 years), in chilled, and heparinized vacutainer tubes. These were centrifuged at $3000 \boldsymbol{g}$ within $30 \mathrm{~min}$. Frozen plasma aliquots were stored at $-20{ }^{\circ} \mathrm{C}$ until analysis.

\section{RIA for obestatin}

The antibodies and the synthesized peptide were used to develop a specific RIA. For preparation of tracer, the peptide was labelled with ${ }^{125} \mathrm{I}$ (Amersham International, Amersham) using the chloramine-T method as described elsewhere (28). The assay was constructed as follows; standards and unknown samples were incubated with tracer $(30000 \mathrm{cpm} /$ tube $)$ and primary antibodies, at a dilution producing 30\% bound radioactivity, for 3 days at $+4{ }^{\circ} \mathrm{C}$. All standards and samples were assayed in duplicate. Antibody-bound radioactivity was separated from free tracer by adding a second antibody, goat anti-rabbit IgG coupled to a solid phase (decanting suspension 3, Pharmacia Biotech, Uppsala, Sweden). The antibody-bound radioactivity was then measured in a $\gamma$-counter (Auto- $\gamma$, Wallac, Pharmacia Biotech) and the data were calculated with a logit-log transformation program (Multicalc, Wallac).
Plasma samples were analysed pre-diluted 1:4 in assay buffer. All chemicals used were of pro analysis grade (Merck). Dilutions in the RIA were performed in the assay buffer, which was a $0.05 \mathrm{M}$ sodium phosphate buffer at $\mathrm{pH} 7.4$, with $0.15 \mathrm{M}$ sodium chloride, $0.02 \%$ sodium azide, 0.2\% BSA and 0.5\% Tween 20 .

\section{Other assays}

Circulating concentrations of chromogranin A (CgA) and gastrin were measured with commercially available kits (Eurodiagnostica, Malmö, Sweden). Total ghrelin was also measured, using a commercial kit (Linco Research, St Louis, MI, USA) in 21 of these patients $(23,25)$. The reference interval for ghrelin was $<2 \mu \mathrm{g} / \mathrm{l}(23,25)$.

\section{Correlations}

A possible correlation was sought between the expression of obestatin in the neoplastic tissue and plasma obestatin levels. Furthermore, the data for obestatin expression in the neoplastic tissue, and plasma obestatin concentration were correlated with clinicopathological parameters of each patient such as patient's body mass index (BMI), size of the lesion (volume calculated from the measured diameter of tumours), circulating concentrations of ghrelin, gastrin and CgA. Correlations were calculated using linear regression.

\section{Approval by the ethics committee}

The research protocol was reviewed and approved by the local research ethics board at Uppsala University Hospital.

\section{Results}

\section{Immunohistochemistry}

Scattered obestatin-IR cells were identified in the fundus and to a lesser extent in corpus and antrum mucosa. These cells were located mainly in the deeper third of the glandular crypts.

The IHC expression of general ( $\mathrm{CgA}$ and synaptophysin) and specific (VMAT-2, serotonin and somatostatin) neuro-endocrine markers in neoplastic and foci of endocrine cell hyperplasia was similar to that previously reported (23, 25). Thus, VMAT-2 was considered specific for the ECL-CCs and was not expressed in ghrelinomas. The latter tumours did not reveal any immunoreactivity with the other specific endocrine cell markers examined. When the immunostaining results with the two VMAT-2 antibodies were compared, no differences were seen regarding the frequency or distribution of IR cells in normal gastric mucosa, in peritumorous mucosa or in gastric endocrine tumours. 


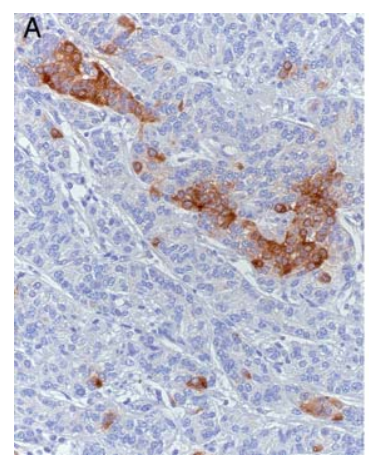

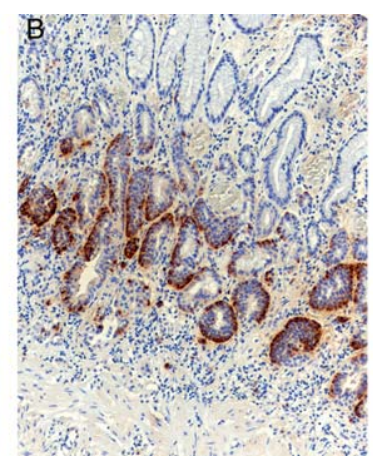

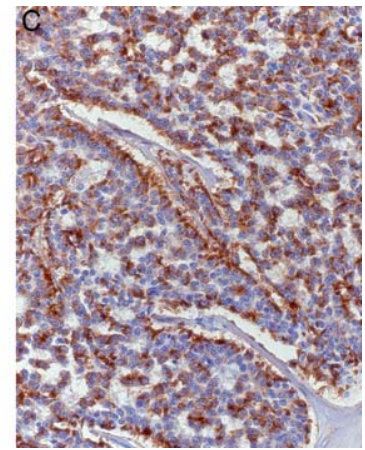

Figure 1 Immunostaining for obestatin. (A) Type I ECL-CC, groups of obestatin-IR tumour cells are visible focally. (B) Peritumorous mucosa in a type I ECL-CC case with numerous foci of obestatin cell hyperplasia occurring in various patterns (diffuse, linear and nodular). (C) A malignant ghrelinoma expressing obestatin in the vast majority of neoplastic cells. Original magnification X200 in figures (A) and (C) and X100 in (B).
Obestatin-IR cells were identified in 35 of 37 of the type I ECL-CCs. In most tumours, the incidence of obestatin-IR tumour cells was $5-10 \%$, in eight of the cases between 15 and 80\% (Fig. 1A).

Patterns of endocrine cell hyperplasia were seen as described in a previous study (29). Numerous foci of obestatin cell hyperplasia were found in the mucosa surrounding type I ECL-CCs. In these foci, diffuse, linear and nodular hyperplasia patterns occurred in various combinations (Fig. 1B); the most common was a combination of all three (Fig. 1B). Only in two cases no obestatin cell hyperplasia was identified; in these mucosa areas, intestinal metaplasia predominated.

All three type II ECL-CCs contained occasional obestatin-IR tumour cells. In one case, the mucosa adjacent to the tumour showed diffuse and linear obestatin cell hyperplasia; in the other two, only a diffuse pattern was seen. The obestatin-IR cells in the foci of endocrine cell hyperplasia were fewer than in those found in the corresponding areas in type I ECL-CCs.

Four out of nine cases of the type III ECL-CCs contained obestatin-IR cells. In three of them, occasional obestatin-IR tumour cells were present, whereas in the fourth case about $10 \%$ was present. In the mucosa surrounding the type III ECL-CCs, slight diffuse obestatin-IR cell hyperplasia was observed in five cases. In one of them, a few foci displayed a linear obestatin cell hyperplasia pattern.

The non-ECL-CC case expressed obestatin in about $5 \%$ of the neoplastic cells, without obestatin-IR cell hyperplasia in the peritumorous mucosa.

Both ghrelinomas expressed obestatin, in one case virtually in all tumour cells; and vast majority in the other. In the latter case, the immunoreactivity of the tumour cells facing the fibrovascular stroma was stronger (Fig. 1C). No endocrine cell hyperplasia was detected in the peritumorous mucosa of these tumours.

None of the eleven PDECs contained obestatin-IR cells but in the mucosa adjacent to the tumour, a diffuse hyperplasia pattern of obestatin/ghrelin-IR cells was observed in two large-cell PDECs, and a slight diffuse and linear hyperplasia pattern in another two large cell PDECs and in one small cell PDEC. However, the linear pattern of obestatin-IR cell hyperplasia in these cases was limited to a few glands.

Obestatin-IR cells also occurred in metastatic lesions, often in a frequency and distribution pattern similar to that in the primary tumours.

\section{Double immuostaining}

All obestatin-IR cells in normal mucosa, in foci of endocrine cell hyperplasia (Fig. 2A) and in tumour cells (Fig. 2B) displayed ghrelin immunoreactivity. Furthermore, the cytoplasmic distribution patterns of the two peptides agreed. In tumours, and in areas of endocrine cell hyperplasia, the intensity of obestatin and ghrelin immunoreactivity varied slightly, producing variable tints of yellow in the fusion images.

In normal gastric mucosa, only occasional obestatin and ghrelin-IR cells displayed VMAT-2 immunoreactivity, i.e. the vast majority remained non-IR to the transporter protein (Fig. 2C). In foci of nodular endocrine cell hyperplasia identified by obestatin/ghrelin immunoreactivity, occasional cells co-expressed VMAT2 and vice versa. In the remaining patterns of endocrine cell hyperplasia, no co-localization occurred (Fig. 2D). Furthermore, the tumour cells showing immunoreactivity to obestatin and ghrelin also expressed the transporter, except for the ghrelinoma. The same results were obtained with both VMAT-2 antibodies.

\section{Plasma concentrations}

The sensitivity of the obestatin RIA was $<4 \mathrm{fmol} /$ tube. Since plasma samples were assayed diluted $1: 4$, the functional detection limit of the assays was $<0.16 \mathrm{nmol} / \mathrm{l}$. The antibodies were used in a final dilution of 1:30 000. The overall assay variation was $<10 \%$. From the 67 healthy individuals the reference interval for obestatin was calculated to range between 0.7 and $2.0 \mathrm{nmol} / \mathrm{l}$.

In the 31 patients in whom plasma obestatin was measured, four patients with type I, one with ghrelinoma and one with PDEC had slightly increased concentrations. However, the previously described patient with a ghrelinoma, who had $\sim 1000$-fold 

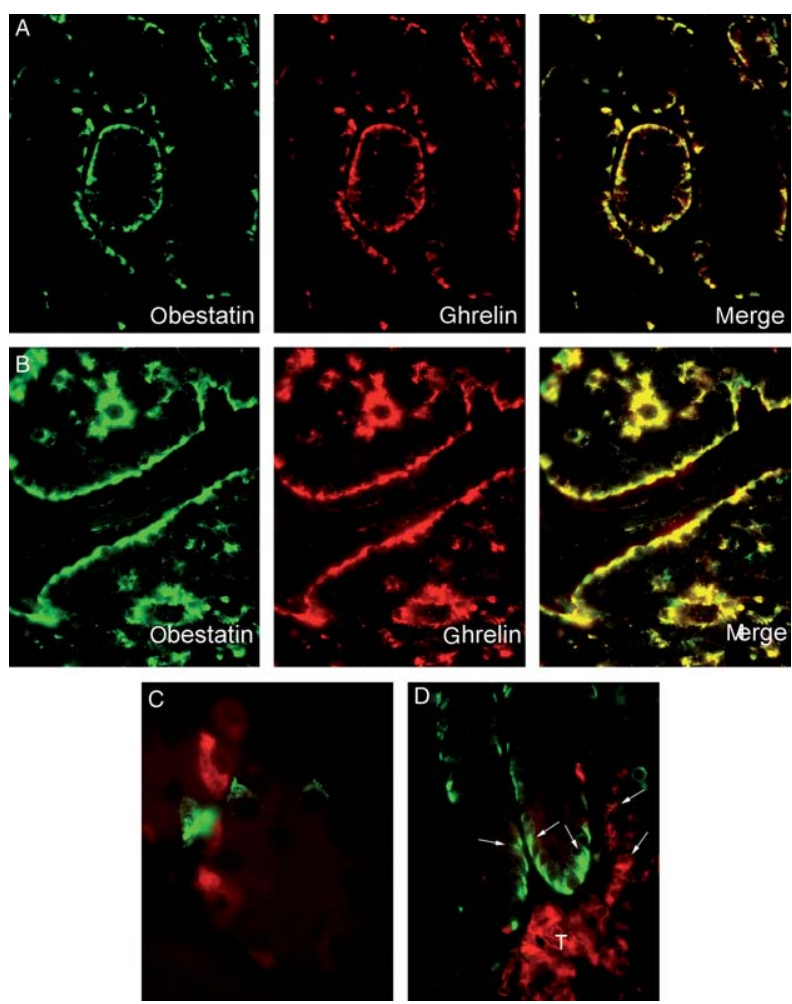

Figure 2 (A) Mucosa adjacent to a type I ECL-CC, doubleimmunostained for obestatin (green) and ghrelin (red). Obestatin and ghrelin-IR cells show diffuse and linear hyperplasia patterns. Co-localization (yellow) depicts that obestatin and ghrelin are expressed with the same cytoplasmic distribution in the same cells. (B) A malignant ghrelinoma, double-immunostained for obestatin (green) and ghrelin (red). Co-localization (yellow) shows that obestatin and ghrelin are expressed with the same cytoplasmic distribution in virtually the same tumour cells. (C) Normal fundus mucosa, double-immunostained for obestatin (green) and VMAT-2 (red). There is no co-localization between obestatin and VMAT-2. (D) Type I ECL-CC and mucosa adjacent to tumour are doubleimmunostained for obestatin (green) and VMAT-2 (red). In foci of endocrine cell hyperplasia (arrows), obestatin- and VMAT-2-IR cells show diffuse and linear hyperplasia and without co-localization. Adjacent tumour cells (T) show only VMAT-2 immunoreactivity.

increased concentration of ghrelin had only a slightly increased concentration of obestatin (3.5 nmol/l) (25). The patient with a type III ECL-CC who suffered from atypical carcinoid syndrome had an obestatin concentration within the reference range. The obestatin, $\mathrm{CgA}$ and gastrin concentrations are summarized in Table 3. All patients except one had normal kidney function.

\section{Correlations}

No correlations were found when the incidence of obestatin-IR tumour cells or the concentration of plasma measurements of obestatin were compared with patient's BMI, tumour size and the circulating concentrations of ghrelin, gastrin and $\mathrm{CgA}$, or when the incidence of obestatin-IR tumour cells was compared with the concentration of plasma obestatin (data not shown).

\section{Discussion}

Traditionally, ECL-cells have been characterized by VMAT-2 expression. Our results show that only a minority of VMAT-2-IR cells in the normal gastric mucosa co-express obestatin/ghrelin. Conversely, most obestatin/ghrelin cells fail to show VMAT-2 immunoreactivity. The same inhomogeneous immunostaining pattern was observed in foci of endocrine cell hyperplasia of nodular pattern. However, in endocrine tumours another pattern occurred; all endocrine tumours co-expressed VMAT-2 and obestatin/ghrelin. In an earlier study, the ghrelin cells were reported to be VMAT-2-IR in human normal mucosa (17). That report was based on a comparison of immunostained $2 \mu \mathrm{m}$ consecutive sections, and the results were corroborated by ultrastructural investigation with double immunogold labelled antibodies. Those findings partly disagree with the present results where only a minority of obestatin-/ghrelin-IR cells co-expressed VMAT-2, suggesting that only a few obestatin/ghrelin cells has VMAT-2 in common with ECL-cells. This finding is further supported by the fact that obestatin/ghrelin expressing cells in foci of endocrine cell hyperplasia were only occasionally IR to the transporter protein. The disparity between the results of these two investigations may be attributed to the different techniques used.

The cause of the different VMAT-2 immunostaining patterns in obestatin/ghrelin cells may depend on their functional state. Another explanation may be that different obestatin/ghrelin subpopulations exist where the absence of VMAT-2 indicates lack of amine production. It is believed that neuroendocrine cells produce both peptide hormones and amines. However, obestatin/ghrelin cells may produce another biogenic amine than histamine. The infrequent expression of VMAT-2 in obestatin/ghrelin cells may indicate that other transporter proteins might be present.

In contrast to the observations made in diffuse and linear endocrine cell hyperplasia, the co-localization studies performed on focally hyperplastic gastric mucosa of nodular pattern identified by VMAT-2, showed that a minority of VMAT-2-IR cells expressed obestatin and ghrelin. Furthermore, in ECL-CCs, all tumour cells that were obestatin- and ghrelin-IR also expressed VMAT-2. An analogous finding was previously presented when consecutive sections from various types of ECL-CCs were immunostained for VMAT-2 and ghrelin (23). It is thought that via the hyperplasia-dysplasia-neoplasia sequence the nodular hyperplasia pattern is a later event, when compared with diffuse and linear patterns, and is considered to be 
Table 3 Clinical, biochemical and tumour characteristics in a subgroup of patients.

\begin{tabular}{|c|c|c|c|c|c|c|c|c|}
\hline $\begin{array}{l}\text { Age (yrs) } \\
\text { /gender }\end{array}$ & $\begin{array}{l}\text { BMI } \\
\left(\mathrm{kg} / \mathrm{m}^{2}\right)\end{array}$ & $\begin{array}{l}\text { Diameter } \\
(\mathrm{mm})\end{array}$ & TNM/grade & $\begin{array}{l}\text { Obestatin-IR } \\
\text { tumour cells }\end{array}$ & $\begin{array}{l}\text { Obestatin } \\
\text { (nmol/l) }\end{array}$ & $\begin{array}{l}\text { Total ghrelin } \\
(\mu \mathrm{g} / \mathrm{l})\end{array}$ & $\begin{array}{l}\text { Gastrin } \\
(\mathrm{pmol} / \mathrm{l})\end{array}$ & $\begin{array}{l}\text { CgA } \\
(\mathrm{nmol} / \mathrm{l})\end{array}$ \\
\hline \multicolumn{9}{|c|}{ Type I ECL-CCs $(n=15)$} \\
\hline $61 / F$ & 26.1 & 2 & T1N0M0/I & $1 \%$ & 1.18 & 0.65 & 106 & 4.6 \\
\hline $72 / F$ & 28.6 & 10 & T1N0M0/I & $2 \%$ & 1.46 & 0.78 & 450 & 10 \\
\hline $80 / \mathrm{M}$ & 25.2 & 7 & T1mN0Mo/I & $1 \%$ & 1.16 & 0.52 & 1670 & 5.2 \\
\hline $62 / F$ & 28.8 & 3 & T1mN0Mo/I & $2 \%$ & 1.54 & $\mathrm{NE}$ & 299 & 11.2 \\
\hline $56 / F$ & 33.2 & 1.5 & T1mN0Mo/I & $3 \%$ & 1.12 & $\mathrm{NE}$ & 389 & 5.8 \\
\hline $54 / F$ & 33 & 5 & T1mN0M0/I & $5 \%$ & 1.33 & NE & 394 & 32 \\
\hline $52 / \mathrm{M}$ & 22.6 & 10 & T1mNOMO/I & $50 \%$ & 2.38 & 1.08 & 452 & 15.1 \\
\hline $74 / F$ & 21.1 & 2.2 & T1mN0Mo/I & $50 \%$ & 1.42 & NE & 1040 & 4.2 \\
\hline $47 / F$ & 37.4 & 2 & T1mN0Mo/I & $80 \%$ & 2.93 & 0.93 & 214 & 4.1 \\
\hline $64 / M$ & 22.2 & 5 & T1mN0M0/I & $80 \%$ & 1.41 & NE & 495 & 8.7 \\
\hline $65 / F$ & 29.6 & 25 & T2NOMO/Ila & Non-IR & 1.39 & NE & 1280 & 6.1 \\
\hline $55 / F$ & $\mathrm{NE}$ & 23 & T2N0M0/Ila & $1 \%$ & 2.32 & 0.68 & 546 & 7.5 \\
\hline $65 / \mathrm{M}$ & 24.5 & 12 & T2mNOM0/Ila & $10 \%$ & 1.6 & 1.02 & 1360 & 25.2 \\
\hline \multicolumn{9}{|c|}{ Type II ECL-CCs $(n=2)$} \\
\hline $48 / F$ & 27.4 & 0.5 & T1mN0M0/I & $1 \%$ & 1.63 & 1.85 & $308^{a}$ & 61.5 \\
\hline $47 / \mathrm{M}$ & 22.8 & 25 & $\mathrm{~T} 2 \mathrm{mN} 1 \mathrm{MO} / \mathrm{IIIb}$ & $3 \%$ & 1.12 & 1.51 & $62600^{a}$ & 305 \\
\hline \multicolumn{9}{|c|}{ Type III ECL-CCs $(n=8)$} \\
\hline $60 / F$ & 20.7 & 7 & T1N0M0/I & $1 \%$ & 1.24 & NE & 26 & 2.3 \\
\hline $44 / F$ & 30 & 22 & T2N1M0/IIIb & Non-IR & 1.44 & 0.71 & 18 & 5.4 \\
\hline $60 / \mathrm{M}$ & 28.7 & 11 & T2N1M0/IIIb & $1 \%$ & 0.88 & NE & 27 & 11.7 \\
\hline $63 / \mathrm{M}$ & 25.5 & 14 & T2N0M1/IV & $1 \%$ & 1.76 & 0.63 & 88 & 5.5 \\
\hline $77 / F$ & 21 & 25 & T2N0M1/IV & $10 \%$ & 1.38 & 0.82 & $337^{a}$ & $1080^{b}$ \\
\hline $72 / \mathrm{M}$ & 21 & 11 & T2N1M1/IV & Non-IR & 1.39 & 1.67 & 13.2 & 18.3 \\
\hline 62/M & 15.3 & 45 & T4N1M1/IV & Non-IR & 1.33 & 0.79 & $127^{\mathrm{a}}$ & 515 \\
\hline $40 / F$ & 20 & 55 & T4mN1M1/IV & Non-IR & 1.38 & 0.69 & 26 & 116 \\
\hline \multicolumn{9}{|c|}{ Malignant ghrelinoma $(n=1)$} \\
\hline $\begin{array}{l}47 / \mathrm{M} \\
\text { PDECs }(n\end{array}$ & 32 & 40 & T2N1M1/IV & $100 \%$ & 3.51 & 2100 & 42 & 19.4 \\
\hline $61 / \mathrm{F}^{\mathrm{c}}$ & 23.7 & 100 & T3N1M1/IV & Non-IR & 1.72 & 1.17 & $423^{a}$ & 50 \\
\hline $58 / F^{d}$ & 31.1 & 90 & T3N1M1/IV & Non-IR & 1.81 & 0.43 & $77^{\mathrm{a}}$ & 8.4 \\
\hline $46 / \mathrm{M}^{\mathrm{d}}$ & 19.5 & 100 & T4N1M1/IV & Non-IR & 3.55 & 0.52 & 33 & 92 \\
\hline
\end{tabular}

Age (yrs), years; F, female; M, male; diameter: the largest dimension of the tumour is given; TNM/grade according to Rindi et al. (27); m, multiple; obestatin (nmol/l): reference range $0.7-2 \mathrm{nmol} / \mathrm{l}$; total ghrelin $(\mu \mathrm{g} / \mathrm{l})$ : reference range $<2 \mu \mathrm{g} / \mathrm{l}$; to convert ghrelin values to nmol/l multiply by 0.30 ; $\mathrm{NE}$, not evaluated; gastrin (pmol/l): reference range $<60 \mathrm{pmol} / /$; $\mathrm{CgA}$ (nmol/l): reference range $<4 \mathrm{nmol} / \mathrm{l}$; ECL-CCs, enterochromaffin-like cell carcinoids; PDECs, poorly differentiated endocrine carcinomas; Non-IR, non-immunoreactive.

aProton pump inhibitor treatment.

bPatient with impaired kidney function.

${ }^{\mathrm{c}}$ Small cell PDEC.

${ }^{\mathrm{d}}$ Large cell PDEC.

a premalignant stage. It can be assumed that a subgroup of hyperplastic/neoplastic ECL-cells can adopt obestatin/ghrelin cell characteristics. It cannot be excluded that these lesions are comprised by multipotent hyperplastic/neoplastic cells that express both features of ECL- and obestatin/ghrelin cells. However, it is also possible that these hyperplastic/neoplastic cells constitute a separate cell population derived from the small subpopulation of obestatin/ghrelin cells that express VMAT-2 in the normal gastric mucosa. On the other hand, all the tumour cells of the two ghrelinomas remained non-IR to the VMAT- 2 antiserum, both in the primary tumours and in metastases, further supporting that they have their histogenetic origin in the nonVMAT-2 expressing ghrelin cells of the gastric mucosa (25). Forthcoming IHC studies on the ultrastructural level may address these questions.
As previously shown for ghrelin, foci of endocrine cell hyperplasia IR to obestatin were identified in peritumorous mucosa of gastric endocrine tumours (23). It is still not known why foci of obestatin/ghrelin cell hyperplasia occur, as ghrelin is independent from gastrin tropic effect (30).

Several studies have reported that the plasma ghrelin concentration remained within the reference range despite the presence of the hormone in neuroendocrine tumours $(23,24,31)$. The only exceptions reported include one malignant gastric and one pancreatic ghrelinoma, both presenting a 1000-fold elevated total plasma ghrelin concentration $(24,25)$. In agreement with the data on plasma ghrelin concentrations, we were unable to identify patients with grossly increased obestatin concentrations, irrespective of the presence of obestatin-IR tumour cells. Furthermore, the occurrence 
of obestatin-IR cells in the neoplastic parenchyma was not correlated to the clinico-pathological parameters examined. The antibodies used in this study are directed towards the two different hormones, obestatin and ghrelin, which are the cleavage products of preproghrelin. However, we cannot rule out the possibility that in some instances the antibodies detect the preproghrelin peptide. It is not known exactly when during the storage and secretion process, the preoprohormone is cleaved into ghrelin and obestatin, but the two peptides seem to have different biological effects and their plasma concentrations do not correlate to each other, indicating that they are cleaved and function as two independent hormones.

Some patients in this study had a slightly increased plasma obestatin concentration, whose cause is not clear, but it was not correlated to any of the various clinico-pathological parameters investigated (tumour size, patients' BMI or circulating levels of ghrelin, gastrin and $\operatorname{CgA}$ ). Of particular interest is the ghrelinoma patient who presented with a 1000-fold increased concentration of circulating total ghrelin, whereas obestatin was $\sim 1$.5-fold increased, despite the co-localization of the two peptides. It is conceivable that obestatin-IR cells in these lesions are unable to release the hormone into the circulation, or that the amount of hormone released is too little to affect plasma levels. Another possible explanation could be that obestatin is further processed immediately after its release into the circulation, to products not identified by our RIA. However, in most patients examined, the circulating levels of ghrelin and obestatin are very low and it is plausible that both hormones exert their major biological effect by paracrine or autocrine actions.

In conclusion, we have found that ghrelin and obestatin are expressed in the same cells in the gastric mucosa and gastric endocrine tumours. Occasional obestatin-/ghrelin-IR cells in the gastric mucosa expressed VMAT-2, whereas this transporter protein was demonstrated in all the neoplastic obestatin/ghrelin expressing cells in ECL-CCs. However, the two ghrelinomas displayed obestatin immunoreactivity, though lacking VMAT-2-IR cells. These results indicate that obestatin/ghrelin-IR cells differ chiefly from VMAT-2-IR cells.

\section{Declaration of interest}

There is no conflict of interest that could be perceived as prejudicing the impartiality of the research reported.

\section{Funding}

This work was supported by the Swedish Cancer Society, the Selander Foundation and the Lions Foundation for Cancer Research at Uppsala University Hospital, and also by the Cancer Research Foundations at Ryhov County Hospital and St Olav University Hospital in Trondheim.

\section{References}

1 Zhang JV, Ren PG, Avsian-Kretchmer O, Luo CW, Rauch R, Klein C \& Hsueh AJ. Obestatin, a peptide encoded by the ghrelin gene, opposes ghrelin's effects on food intake. Science $2005 \mathbf{3 1 0}$ 996-999.

2 Lauwers E, Landuyt B, Arckens L, Schoofs L \& Luyten W. Obestatin does not activate orphan G protein-coupled receptor GPR39. Biochemical and Biophysical Research Communications 2006351 $21-25$.

3 Holst B, Egerod KL, Schild E, Vickers SP, Cheetham S, Gerlach LO, Storjohann L, Stidsen CE, Jones R, Beck-Sickinger AG \& Schwartz TW. GRP 39 signaling is stimulated by zinc ions but not by obestatin. Endocrinology $2007 \mathbf{1 4 8} 13-20$.

4 Chartrel N, Alvear-Perez R, Leprince J, Iturrioz X, Reaux-Le Goazigo A, Audinot V, Chomarat P, Coge F, Nosjean O, Rodriguez M, Galizzi JP, Boutin JA, Vaudry H \& Llorens-Cortes C. Comment on 'Obestatin, a peptide encoded by the ghrelin gene, opposes ghrelin's effects on food intake'. Science 2007315766 author reply 766 .

5 Samson WK, White MM, Price C \& Ferguson AV. Obestatin acts in brain to inhibit thirst. American Journal of Physiology. Regulatory, Integrative and Comparative Physiology 2007292 R637-R643.

6 Carlini VP, Schioth HB \& Debarioglio SR. Obestatin improves memory performance and causes anxiolytic effects in rats. Biochemical and Biophysical Research Communications 2007352 907-912.

7 Huda MS, Durham BH, Wong SP, Deepak D, Kerrigan D, McCulloch P, Ranganath L, Pinkney J \& Wilding JP. Plasma obestatin levels are lower in obese and post-gastrectomy subjects, but do not change in response to a meal. International Journal of Obesity 200832 129-135.

8 Guo ZF, Zheng X, Qin YW, Hu JQ, Chen SP \& Zhang Z. Circulating preprandial ghrelin to obestatin ratio is increased in human obesity. Journal of Clinical Endocrinology and Metabolism 200792 1875-1880.

9 Wren AM, Seal LJ, Cohen MA, Brynes AE, Frost GS, Murphy KG, Dhillo WS, Ghatei MA \& Bloom SR. Ghrelin enhances appetite and increases food intake in humans. Journal of Clinical Endocrinology and Metabolism 2001865992.

10 Kojima M, Hosoda $H$, Date $Y$, Nakazato M, Matsuo H \& Kangawa K. Ghrelin is a growth-hormone-releasing acylated peptide from stomach. Nature 1999402 656-660.

11 Levin F, Edholm T, Schmidt PT, Gryback P, Jacobsson H, Degerblad M, Hoybye C, Holst JJ, Rehfeld JF, Hellstrom PM \& Naslund E. Ghrelin stimulates gastric emptying and hunger in normal-weight humans. Journal of Clinical Endocrinology and Metabolism 200691 3296-3302.

12 Tack J, Depoortere I, Bisschops R, Delporte C, Coulie B, Meulemans A, Janssens J \& Peeters T. Influence of ghrelin on interdigestive gastrointestinal motility in humans. Gut 200655 327-333.

13 Tack J, Depoortere I, Bisschops R, Verbeke K, Janssens J \& Peeters T. Influence of ghrelin on gastric emptying and meal-related symptoms in idiopathic gastroparesis. Alimentary Pharmacology $\mathcal{E}$ Therapeutics 200522 847-853.

14 Binn M, Albert C, Gougeon A, Maerki H, Coulie B, Lemoyne M, Rabasa Lhoret R, Tomasetto C \& Poitras P. Ghrelin gastrokinetic action in patients with neurogenic gastroparesis. Peptides 200627 1603-1606.

15 Date Y, Kojima M, Hosoda H, Sawaguchi A, Mondal MS, Suganuma T, Matsukura S, Kangawa K \& Nakazato M. Ghrelin, a novel growth hormone-releasing acylated peptide, is synthesized in a distinct endocrine cell type in the gastrointestinal tracts of rats and humans. Endocrinology 2000141 4255-4261.

16 Gronberg M, Tsolakis AV, Magnusson L, Janson ET \& Saras J. Distribution of obestatin and ghrelin in human tissues: 
immunoreactive cells in the gastrointestinal tract, pancreas, and mammary glands. Journal of Histochemistry and Cytochemistry 200856 793-801.

17 Rindi G, Necchi V, Savio A, Torsello A, Zoli M, Locatelli V, Raimondo F, Cocchi D \& Solcia E. Characterisation of gastric ghrelin cells in man and other mammals: studies in adult and fetal tissues. Histochemistry and Cell Biology 2002117 511-519.

18 Erickson JD, Schafer MK, Bonner TI, Eiden LE \& Weihe E. Distinct pharmacological properties and distribution in neurons and endocrine cells of two isoforms of the human vesicular monoamine transporter. PNAS 199693 5166-5171.

19 Jakobsen AM, Andersson P, Saglik G, Andersson E, Kolby L, Erickson JD, Forssell-Aronsson E, Wangberg B, Ahlman H \& Nilsson O. Differential expression of vesicular monoamine transporter (VMAT) 1 and 2 in gastrointestinal endocrine tumours. Journal of Pathology 2001195 463-472.

20 Papotti M, Cassoni P, Volante M, Deghenghi R, Muccioli G \& Ghigo E. Ghrelin-producing endocrine tumors of the stomach and intestine. Journal of Clinical Endocrinology and Metabolism $2001 \mathbf{8 6}$ 5052-5059.

21 Rindi G, Savio A, Torsello A, Zoli M, Locatelli V, Cocchi D, Paolotti D \& Solcia E. Ghrelin expression in gut endocrine growths. Histochemistry and Cell Biology 2002117 521-525.

22 Srivastava A, Kamath A, Barry SA \& Dayal Y. Ghrelin expression in hyperplastic and neoplastic proliferations of the enterochromaffin-like (ECL) cells. Endocrine Pathology 200415 47-54.

23 Tsolakis AV, Stridsberg M, Grimelius L, Portela-Gomes GM, Falkmer SE, Waldum HL \& Janson ET. Ghrelin immunoreactive cells in gastric endocrine tumors and their relation to plasma ghrelin concentration. Journal of Clinical Gastroenterology $2008 \mathbf{4 2}$ 381-388

24 Corbetta S, Peracchi M, Cappiello V, Lania A, Lauri E, Vago L, Beck-Peccoz P \& Spada A. Circulating ghrelin levels in patients with pancreatic and gastrointestinal neuroendocrine tumors: identification of one pancreatic ghrelinoma. Journal of Clinical Endocrinology and Metabolism 200388 3117-3120.
25 Tsolakis AV, Portela-Gomes GM, Stridsberg M, Grimelius L, Sundin A, Eriksson BK, Oberg KE \& Janson ET. Malignant gastric ghrelinoma with hyperghrelinemia. Journal of Clinical Endocrinology and Metabolism 200489 3739-3744.

26 Capella C, Solcia E, Sobin L \& Arnold R. Endocrine tumors of the stomach. In WHO Classification of Tumours. Pathology and Genetics. Tumours of the Digestive System, pp 53-57. Eds S Hamilton \& L Aaltonen, Lyon: IARC Press, 2000.

27 Rindi G, Kloppel G, Alhman H, Caplin M, Couvelard A, de Herder WW, Erikssson B, Falchetti A, Falconi M, Komminoth P, Korner M, Lopes JM, McNicol AM, Nilsson O, Perren A, Scarpa A, Scoazec JY \& Wiedenmann B. TNM staging of foregut (neuro) endocrine tumors: a consensus proposal including a grading system. Virchows Archive 2006449 395-401.

28 Stridsberg $\mathrm{M}$, Oberg $\mathrm{K}, \mathrm{Li}$ Q, Engstrom U \& Lundqvist G. Measurements of chromogranin A, chromogranin B (secretogranin I), chromogranin C (secretogranin II) and pancreastatin in plasma and urine from patients with carcinoid tumours and endocrine pancreatic tumours. Journal of Endocrinology 1995144 49-59.

29 Solcia E, Bordi C, Creutzfeldt W, Dayal Y, Dayan AD, Falkmer S, Grimelius L \& Havu N. Histopathological classification of nonantral gastric endocrine growths in man. Digestion $1988 \mathbf{4 1}$ 185-200.

30 Dornonville de la Cour C, Bjorkqvist M, Sandvik AK, Bakke I, Zhao CM, Chen D \& Hakanson R. A-like cells in the rat stomach contain ghrelin and do not operate under gastrin control. Regulatory Peptides 200199 141-150.

31 Ekeblad S, Lejonklou MH, Grimfjard P, Johansson T, Eriksson B, Grimelius L, Stridsberg M, Stalberg P \& Skogseid B. Co-expression of ghrelin and its receptor in pancreatic endocrine tumours. Clinical Endocrinology 200766 115-122.

Received 3 March 2009

Accepted 13 March 2009 